\title{
NEST-SITE RELATIONSHIPS AMONG CAVITY-NESTING BIRDS OF RIPARIAN AND SNOWPOCKET ASPEN WOODLANDS IN THE NORTHWESTERN GREAT BASIN ${ }^{1}$
}

\author{
DAvid S. DoBKIN \\ High Desert Ecological Research Institute, 15 S.W. Colorado Avenue, Suite 300, Bend, OR 97702 \\ AdAm C. RICH \\ High Desert Ecological Research Institute, 15 S.W. Colorado Avenue, Suite 300, Bend, OR 97702
}

\author{
JENNIFER A. PRETARE ${ }^{2}$ \\ U.S. Fish and Wildlife Service, Sheldon-Hart Mountain Refuge Complex, \\ P.O. Box 111, Lakeview, OR 97630 \\ William H. Pyle \\ U.S. Fish and Wildlife Service, Sheldon-Hart Mountain Refuge Complex, \\ P.O. Box 111, Lakeview, OR 97630
}

\begin{abstract}
We examined nest-site and nest-cavity characteristics for six species of cavitynesting birds in montane riparian and snowpocket aspen (Populus tremuloides) woodlands in the northwestern Great Basin. Live trees and snags with DBH $>24 \mathrm{~cm}$ were favored as nest sites by all species. Red-naped Sapsuckers (Sphyrapicus nuchalis) and Northern Flickers (Colaptes auratus) provided different sizes of nest cavities for a suite of nonexcavator species. Flickers preferentially nested in snags; sapsuckers nested primarily in live trees, but used live trees and snags in proportion to their availabilities. Relative abundances of excavators and nonexcavators were associated positively with numbers of cavities. Nest-site variables overlapped extensively among species; Tree Swallows (Tachycineta bicolor) relied heavily on sapsuckers for provision of nest cavities, European Starlings (Sturnus vulgaris) and Mountain Bluebirds (Sialia currucoides) primarily used flicker-excavated cavities, and House Wrens (Troglodytes aedon) used nest cavities across the broadest range of nest-site characteristics. Compass orientation of nest-cavity entrances was strongly bimodal, with most facing east or southwest. Cavity entrances of species that foraged largely outside of riparian woodlands were oriented toward woodland edge, in contrast to nest cavities used by species that foraged largely within riparian woodlands. Snowpocket woodlands were much more extensive than riparian aspen, but birds strongly preferred riparian aspen stands as nesting habitats, presumably due to the scarcity of large aspen in snowpockets. Nest cavities appear to be a limiting resource with high potential for interspecific nest-site competition in these woodlands. Decades of livestock overuse and fire suppression have greatly diminished the availability of large aspen in riparian habitats throughout the region.
\end{abstract}

Key words: Aspen woodland; cavity nesters; cavity orientation; Great Basin; nest-site characteristics; Northern Flicker; Red-naped Sapsucker; riparian woodland.

\section{INTRODUCTION}

Riparian forests and woodlands harbor the most species-rich avifaunas in the arid and semi-arid portions of the western United States (Knopf et al. 1988; Dobkin 1994; Saab et al., in press). Unfortunately, these habitats are focal points of

\footnotetext{
1 Received 16 December 1994. Accepted 30 March 1995.

2 Present address: Department of Environmental Science, Policy, and Management, 218 Wellman Hall, University of California, Berkeley, CA 94720.
}

conflict among competing uses for livestock grazing, timber harvest, recreation, and water diversion for agriculture and domestic consumption (Thomas et al. 1979, Johnson et al. 1985).

Decades of livestock overuse and exclusion of fire by land managers have resulted in extensive loss of woody riparian habitats and ecologically degraded conditions for much of what remains in the Intermountain West (Dobkin 1994, Fleischner 1994). Disruption of ecosystem functioning and alteration of both faunal and floral community composition are the legacy of these long-term impacts in western riparian systems 
(Gruell 1985; Platts et al. 1987; Fleischner 1994; Saab et al., in press).

Cavity-nesting birds are key components of riparian avifaunas in Great Basin aspen (Populus tremuloides) woodlands, the only broad-leaved woodlands in montane areas of this vast region (Billings 1990) that can provide significant nesting habitat for cavity-excavating species. In the mountains of central Nevada, Red-naped Sapsuckers (Sphyrapicus nuchalis) are the primary providers of cavity nest sites in riparian aspen woodlands, and their presence is associated with increased abundances of native, secondary cavity-nesting species (Dobkin and Wilcox 1986). At Hart Mountain National Antelope Refuge in southeastern Oregon, cavity-nesting birds constitute nearly $50 \%$ of all breeding individuals in montane aspen woodlands (Dobkin et al., in prep.).

The conservation importance of rangeland riparian habitats and the paucity of information on riparian avifaunas in the Great Basin prompted us to undertake a long-term study of riparian avifaunas in the northern Great Basin. The purpose of the research reported here was to gain a better understanding of the interrelationships among primary and secondary cavity nesters in montane riparian and snowpocket aspen woodlands by: (1) comparing use to availability of nest sites, (2) evaluating the potential for nest site competition among species based on quantitative assessment of nest site characteristics, and (3) examining the relative dependence of secondary cavity-nesting species on specific cavity excavators.

\section{STUDY AREA}

This study was conducted in the northwestern Great Basin on the 115,000 ha Hart Mountain National Antelope Refuge $\left(42^{\circ} 25^{\prime} \mathrm{N}, 119^{\circ} 40^{\prime} \mathrm{W}\right)$ in southeastern Oregon. The refuge encompasses the entire fault block escarpment of Hart Mountain. Aspen woodlands ranged in elevation from $1,725 \mathrm{~m}$ to $2,300 \mathrm{~m}$, and occurred as narrow ribbons of riparian habitat surrounded by sagebrush steppe, or as dense stands of smaller-stature trees on sideslopes and snowpocket areas in the higher reaches of riparian drainages. Riparian aspen woodlands typically were $<100 \mathrm{~m}$ in width, and areas of snowpocket aspen generally ranged from $100 \mathrm{~m}$ to $300 \mathrm{~m}$ in width. As elsewhere in the Great Basin, woody riparian habitat was extremely limited within these landscapes, and totaled only 317 ha $(<0.003 \%)$ of the entire refuge, including snowpocket aspen stands. Aspen woodland accounted for 262 ha, of which $85 \%$ (223 ha) consisted of snowpocket stands, with the remaining woody riparian habitat composed of willows and other deciduous shrubs.

\section{METHODS}

\section{NEST SITE AVAILABILITY}

In 1991 we estimated densities of tree cavities in aspen woodlands on 25 plots distributed among the five major drainages of the refuge in proportion to total aspen area in each drainage. Because our studies indicated much greater cavitynester use and higher abundances of cavity nesters in riparian aspen compared with snowpocket stands, we placed two-thirds of our plots in riparian woodland. Plots were $100 \mathrm{~m} \times 150 \mathrm{~m}$ (1.5 ha) and were surveyed in October-November so that cavities were not obscured by foliage. For all trees with cavities, we recorded tree species, status (live or dead), height, diameter at breast height $(\mathrm{DBH}=1.4 \mathrm{~m})$, presence of visible shelf fungi (Fomes spp.), number of cavities per tree, cavity height, and compass orientation of cavity entrances. Trees were not climbed in this survey, hence a small but probably significant overestimation of actual cavity availabilities for nonexcavators was caused by inclusion of cavities that were not fully excavated but had sufficient entrance diameters to be counted from ground level.

In 1991 and 1992 we estimated total aspen densities for dead trees (snags) and live trees on the 25 plots surveyed for cavities. In each plot, we established twelve $100 \mathrm{~m}$ strip transects at $12.5 \mathrm{~m}$ intervals perpendicular to each of the main transects, and recorded all woody stems within $1 \mathrm{~m}$ of each transect line. We calculated availabilities of live and dead trees for all trees with $\mathrm{DBH} \geq 12 \mathrm{~cm}$, based on the range of $\mathrm{DBH}$ measurements found in the cavity survey.

\section{AVIAN RELATIVE ABUNDANCES}

We sampled birds during the 1991-1993 breeding seasons in the 25 plots using modified fixedwidth line transects (Emlen 1971, 1977). Six times each year, in three pairs of consecutive morning samples (each pair of samples was separated by three weeks), we walked $150 \mathrm{~m}$ transects for an average of $20 \mathrm{~min}$ each and recorded all birds seen or heard. Statistical analyses of avian rela- 
tive abundances were based on the maximum estimated number of breeding pairs recorded within each plot during the breeding season. For each plot, we calculated the maximum number of breeding pairs for each pair of samples as: maximum number of individual males plus total number of females in excess of maximum number of males plus one half of the maximum number of adults of unknown sex. For the breeding season as a whole, our estimated number of breeding pairs per plot for each species was the highest number obtained by the preceding formula from among the three pairs of samples. This metric was developed (Dobkin et al., unpubl. data) to compensate for the high proportion of unknown-sex detections in monochromatic, relatively nonvocal species $(95 \%$ of European Starling, Sturnus vulgaris, detections; $71 \%$ of Tree Swallow, Tachycineta bicolor, detections), relative to dichromatic or highly vocal species with low proportions of unknown-sex detections $(10 \%$ of Mountain Bluebird, Sialia currucoides, detections; $31 \%$ of House Wren, Troglodytes aedon, detections). Our estimate is of potential breeding numbers-clearly, not all territorial males successfully attract mates and breed, and not all species are characterized by breeding "pairs." The configuration of highly linear, narrow woodlands surrounded by very open habitat created conditions for high detectability of birds in these habitats.

\section{NEST-SITE METRICS}

We recorded nest-site metrics in June and July of 1992 and 1993 for active nests of cavity-nesting birds in the five drainages. Nests were located by following adult birds to tree cavities. The presence of nestlings or a pattern of frequent adult visitation defined active nests. After positive identification of an active nest, the tree was marked and the bird species, tree species, and tree location noted. We collected cavity measurements and other vegetation characteristics after nesting was completed. Reoccupation of a nest cavity by the same species in the subsequent breeding season occurred only twice, once by a Northern Flicker (Colaptes auratus) and once by a European Starling, but each cavity was measured only once to maintain statistical independence.

American Kestrels (Falco sparverius), Downy Woodpeckers (Picoides pubescens), Hairy Woodpeckers $(P$. villosus), and Red-breasted Sapsuck- ers ( $S$. ruber) accounted for single nests and were excluded from our analyses. Virtually all sapsuckers were Red-naped, but data are included from four pairs in which one member of each pair appeared to be a Red-naped $\times$ Red-breasted hybrid. Hybrids of these two species are known from other sites in the region (Johnson and Zink 1983, Johnson and Johnson 1985).

We climbed all nest trees and measured cavity height above ground, tree diameter at cavity height (DCH), compass orientation of cavity entrance, and maximum horizontal and vertical diameters of cavity entrance. We also measured nest tree $\mathrm{DBH}$, and used a clinometer to estimate tree height. Each nest tree was noted as live or dead and characterized as acute, vertical or obtuse depending on tree angle relative to cavity entrance (acute if entrance was on the underside of a leaning tree, obtuse if on the upper side, and vertical if the entrance was on a straight bole). We estimated percent canopy cover above the nest cavity by modifying the formula of Platts et al. (1987) to use three readings recorded with a spherical densiometer.

We also measured distance from each nest tree to woodland edge, with edge defined as the nearest treeline adjacent to an open area devoid of woody riparian vegetation, and which extended for at least $100 \mathrm{~m}$ from the woodland edge.

\section{DATA ANALYSIS}

Univariate analysis of variance (ANOVA) was used to analyze differences in nest-site metrics among species, and multivariate methods were employed to compare overall relationships (Norusis 1993). Assumptions of normality and homoscedasticity were tested with normal probability plots and $F_{\max }$-tests, and data were transformed $\left(\log _{10} ;\right.$ arcsine for percentages) where necessary. We used nonparametric tests where transformations failed to meet parametric assumptions. All metrics with significant ANOVA results were examined further with pairwise multiple comparisons using Tukey's- $b$ test (Day and Quinn 1989).

We used nonparametric Watson one-sample $U^{2}$ tests for circular distributions (Zar 1984) to test for uniform distributions of nest entrance orientations for each excavator species. We tested whether observed nest entrance orientations differed from expected for nonexcavators by generating expected values from the 1991 cavity survey. 

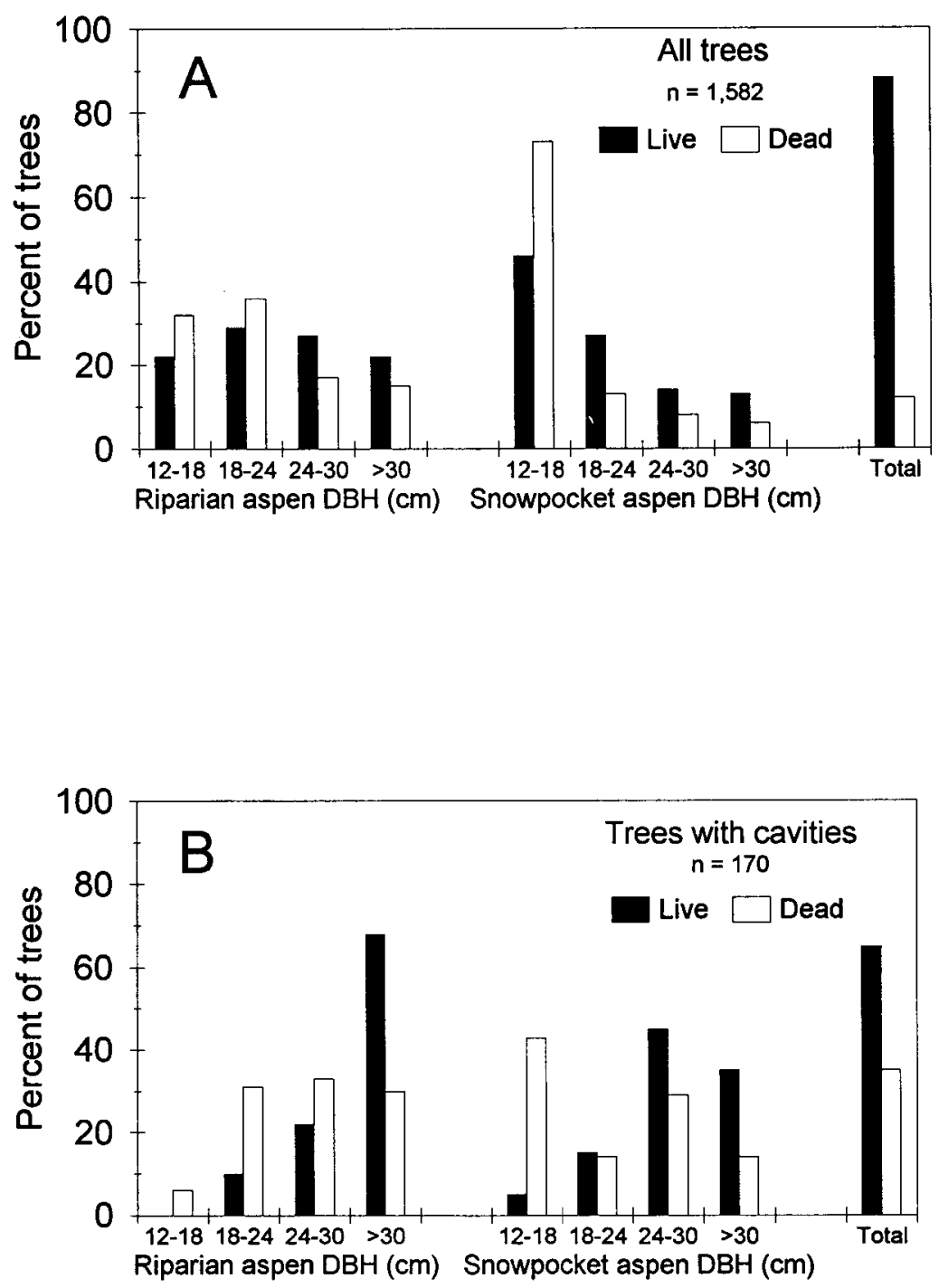

FIGURE 1. Relative availabilities of (A) all live trees and snags with $D B H \geq 12 \mathrm{~cm}$, and (B) of live trees and snags with cavities in riparian and snowpocket aspen woodlands of Hart Mountain National Antelope Refuge in southeastern Oregon.

Significant variables from univariate tests were subjected to cluster analysis using average linkage distances (UPGMA) between groups to generate a dendrogram of species relationships. All significant variables were weighted equally using squared Euclidean distances, and variables with similar means among species were eliminated automatically. The resulting procedure utilized the five most critical variables (horizontal and vertical cavity-entrance diameters, nest cavity height, distance from woodland edge, and nest cavity-entrance orientation).

\section{RESULTS}

\section{NEST SITE AVAILABILITY AND} AVIAN ABUNDANCES

We found 287 cavities in 170 cavity-bearing trees (168 were aspen). Nearly all cavities showed characteristics of excavation or substantial modification by woodpeckers. DBH ranged from 12 $\mathrm{cm}$ to $60 \mathrm{~cm}(\bar{x} \pm \mathrm{SE}=31.8 \pm 0.6)$ for trees with cavities, but trees with $\mathrm{DBH} \geq 12 \mathrm{~cm}$ accounted for only $4 \%$ of all woody stems in riparian aspen and $3 \%$ of all woody stems in snow- 


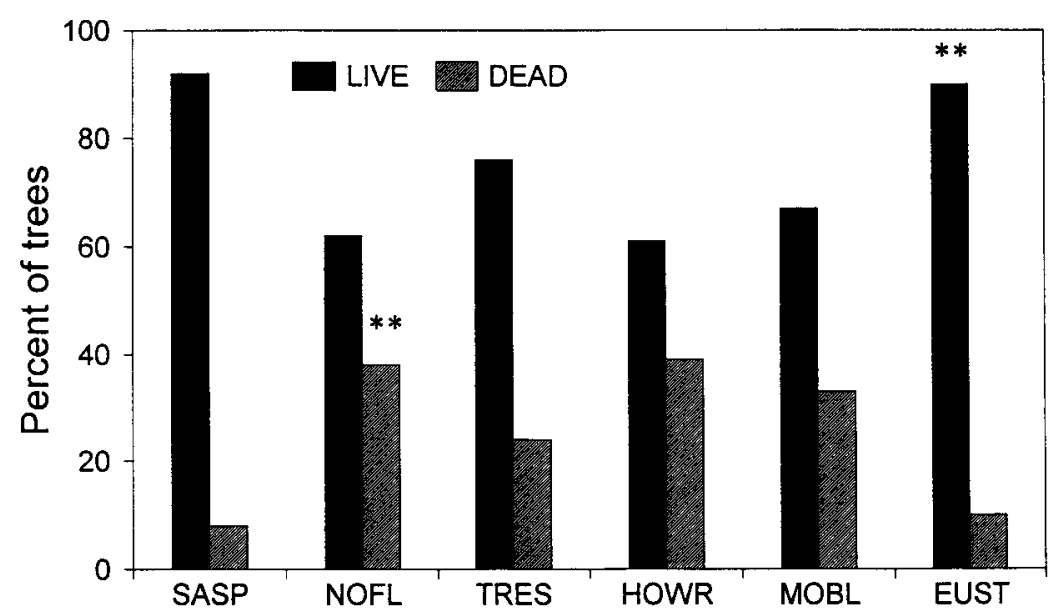

FIGURE 2. Relative use of live and dead trees for nest sites by Red-naped Sapsucker (SASP), Northern Flicker (NOFL), Tree Swallow (TRES), House Wren (HOWR), Mountain Bluebird (MOBL), and European Starling (EUST) in aspen woodlands of Hart Mountain National Antelope Refuge, Oregon, 1992-1993. Observed versus expected use of live trees and snags was tested against availabilities of all trees with DBH $\geq 12 \mathrm{~cm}$ (Fig. 1A) for excavator species, and tested against availabilities of all trees with cavities (Fig. 1B) for secondary cavity nesters (chi-square or binomial test, ${ }^{* *} P<0.01$ ).

pockets. Live trees $\geq 12 \mathrm{~cm} \mathrm{DBH}$ in riparian woodlands were nearly evenly represented across several size classes, in contrast to snowpockets where trees and snags $>24 \mathrm{~cm} \mathrm{DBH}$ were relatively uncommon (Fig. 1A). Snags accounted for $13 \%$ of all trees sampled. Most cavities were in live trees (Fig. 1B), and visible shelf fungi were present on $72 \%$ of all live aspen trunks that had cavities.

Cavity-nesting birds disproportionately used live trees $>30 \mathrm{~cm}$ DBH and seldom used live trees $<24 \mathrm{~cm} \mathrm{DBH}$ for nest sites in riparian woodlands $\left(\chi^{2}=115.7\right.$, df $=3, P<0.001$; Fig. 1B). Snags with $\mathrm{DBH}>24 \mathrm{~cm}$ in riparian woodlands were favored disproportionately for nest sites, and snags $<18 \mathrm{~cm}$ DBH were avoided almost entirely $\left(\chi^{2}=24.2\right.$, df $\left.=3, P<0.001\right)$. In snowpockets, birds preferred live trees $>24 \mathrm{~cm}$ DBH as nest sites, and made little use of live trees $12-18 \mathrm{~cm}$ DBH $\left(\chi^{2}=23.8, \mathrm{df}=1, P<\right.$ 0.001 , which made up nearly half of all live trees $\geq 12 \mathrm{~cm} \mathrm{DBH}$ in snowpocket stands. Too few cavities $(n=7)$ were found in snowpocket snags to evaluate statistically.

Northern Flickers nested in snags more often than expected from snag availability $(P<0.01)$, but sapsuckers used live and dead trees in proportion to tree availability (Fig. $2, P=1.0$ ). Live trees and snags were used in proportion to availability by all secondary cavity nesters except Eu- ropean Starlings, which nested disproportionately in live trees $(P<0.01)$.

Relative abundances of excavators and nonexcavators in 1991 correlated significantly with number of cavities (Spearman correlation coefficient, $r_{\mathrm{s}}=0.50, P=0.01$, and $r_{\mathrm{s}}=0.77, P<$ 0.0001 , for excavators and nonexcavators, respectively), and with number of cavity trees per plot $\left(r_{\mathrm{s}}=0.47, P=0.02\right.$, and $r_{\mathrm{s}}=0.76, P<$ 0.0001 , for excavators and nonexcavators, respectively; Fig. 3).

Estimated relative abundances of the six species occupying portions of the plots in 1991 totaled 181 breeding pairs, indicating the potential for very high utilization of available cavity-bearing trees in the study plots. Although relative abundances increased in 1992 and 1993, both excavator and nonexcavator relative abundances still correlated significantly (all $P<0.005$ ) with the 1991 estimates of cavities and cavity trees per plot. Correlations for nonexcavators $\left(r_{\mathrm{s}}=\right.$ 0.73 to 0.82 ) were stronger than correlations for excavators $\left(r_{\mathrm{s}}=0.50\right.$ to 0.59$)$ in all three years.

\section{NEST-SITE METRICS}

We identified and measured 146 cavity nests (all in aspen) during the 1992 and 1993 nesting seasons. Nests occurred disproportionately between riparian and snowpocket plots $\left(\chi^{2}=29.7, \mathrm{df}=\right.$ $1, P<0.001$ ) with $89 \%$ in riparian woodlands. 


\section{Excavators}

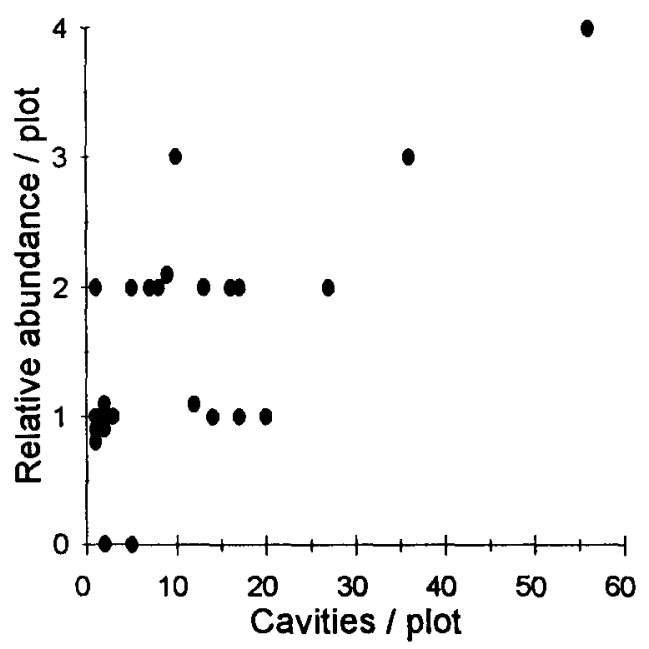

Nonexcavators

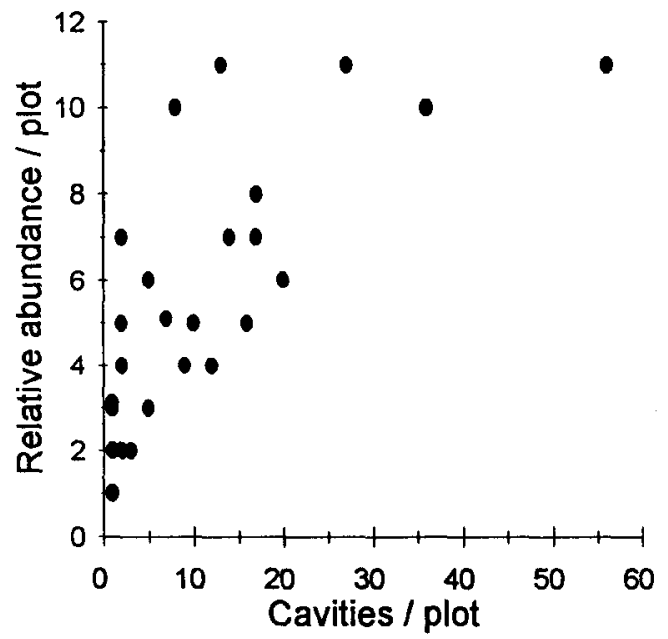

Excavators

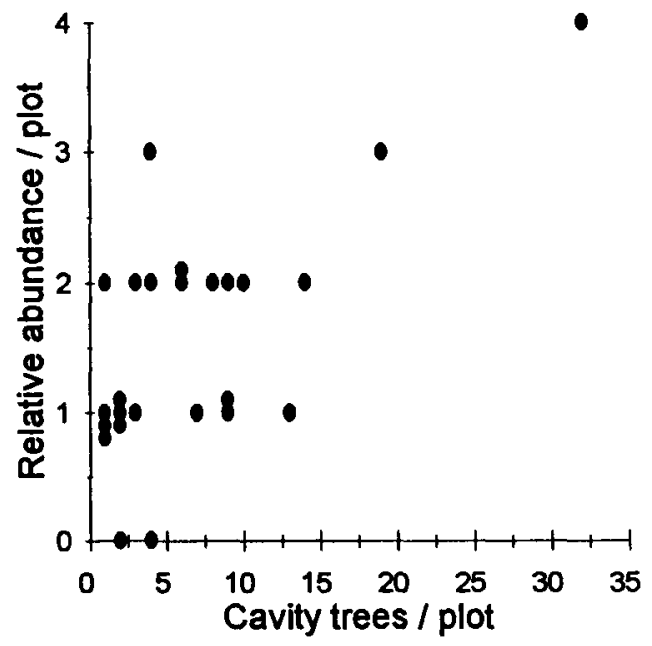

Nonexcavators

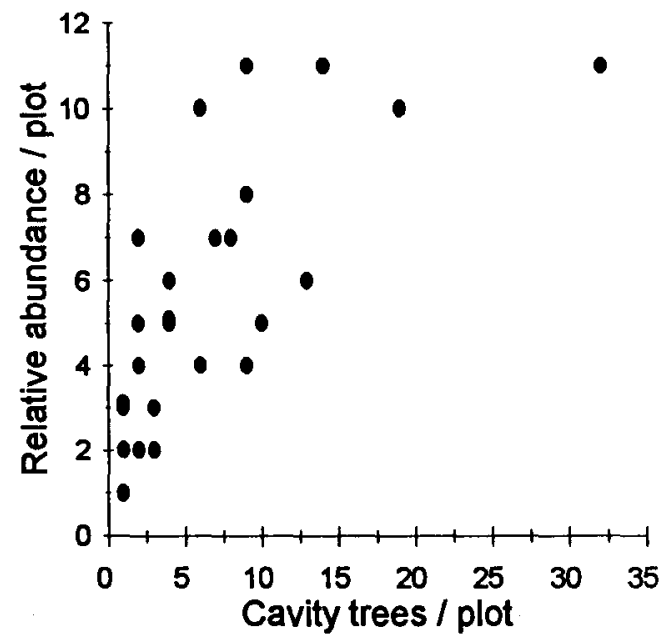

FIGURE 3. Relative abundance of cavity-nesting birds in relation to number of cavities (excavators $r_{\mathrm{s}}=0.50$, $P=0.01$; nonexcavators $r_{\mathrm{s}}=0.77, P<0.0001$ ) and number of cavity trees (excavators $r_{\mathrm{s}}=0.47, P=0.02$; nonexcavators $r_{\mathrm{s}}=0.76, P<0.0001$ ) on 1.5 ha plots in aspen woodlands of Hart Mountain National Antelope Refuge, Oregon, in the 1991 breeding season.

Entrance diameters of nest cavities exhibited a complicated pattern of overlap among species (Table 1). The two excavators, sapsuckers and flickers, exhibited the most extreme difference in mean horizontal and vertical entrance diameters. House Wren nests had the greatest range of cavity entrance diameters ( 3.3 to $9.4 \mathrm{~cm}$ ).

There were no detectable differences among species in nest tree $\mathrm{DBH}, \mathrm{DCH}$, or percent canopy cover, and few discernable differences in nest tree height (Table 1). Nest height contrasted most strongly between flickers, which nested relatively low, and sapsuckers, Tree Swallows, and starlings, which nested relatively high (Table 1). House Wrens exhibited the largest range (11.5 $\mathrm{m}$ ) in nest heights. Sapsuckers and Tree Swallows nested at greater distances from woodland edge than did starlings (Table 1). Starlings and flickers exhibited the greatest propensity to nest along riparian woodland edge (38\% of each species' 


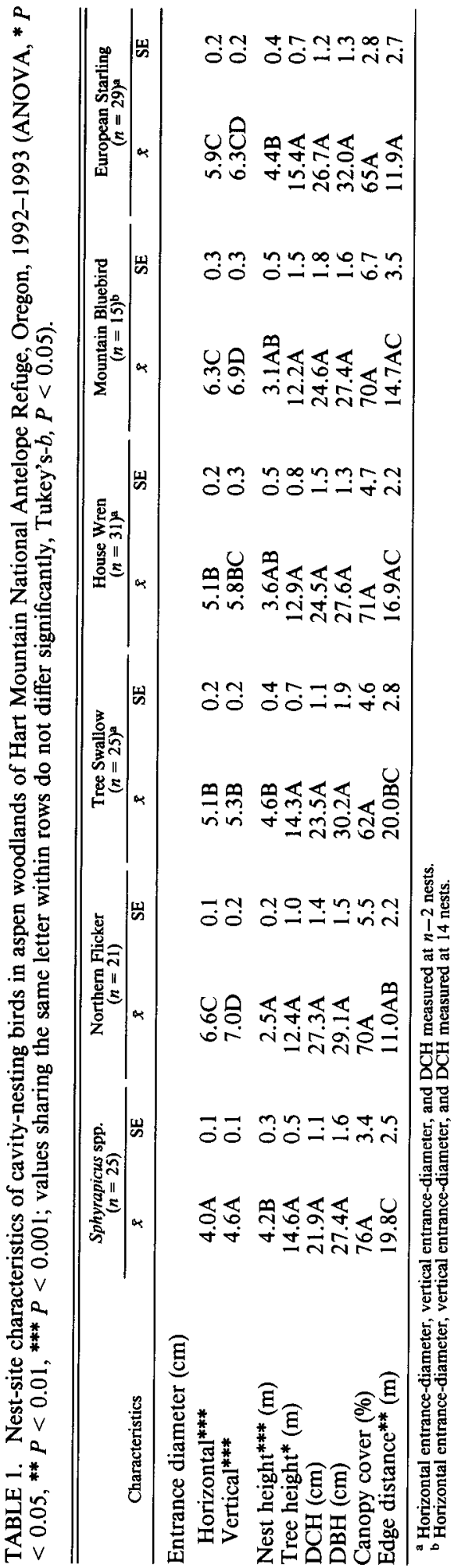

nests), in contrast to the other four species, which ranged from no nests along the edge (sapsuckers) to $20 \%$ of nests (Mountain Bluebirds).

Compass orientations of nest-cavity entrances did not differ between sapsuckers and flickers (Mann-Whitney $U=241.5, n=46, P=0.64$ ). Nest-entrance orientations of woodpeckers were not distributed uniformly (Watson one-sample $U^{2}=0.23, n=46, P<0.05$ ), and exhibited a strongly bimodal pattern with most cavities facing east or southwest (Fig. 4). Although there was no difference overall in nest entrance orientations of excavators and nonexcavators (Fig. 4; $U$ $=2083.0, n=146, P=0.35$ ), nest-entrance orientation for nonexcavators as a group differed from available cavity-entrance orientations $\left(\chi^{2}\right.$ $=14.2, \mathrm{df}=3, P=0.003$ ).

Nonexcavators as a group displayed a bimodal distribution of nest-entrance orientations similar to the pattern found for excavators, with a strong peak for east-facing entrances and a comparatively weaker peak for southwest-facing entrances (Fig. 4). Among nonexcavators, only Mountain Bluebirds differed from other species in nestentrance orientations [comparisons with Tree Swallow $(U=88.0, n=40, P=0.005)$, House Wren $(U=133.5, n=46, P=0.019)$, and European Starling $(U=85.5, n=44, P=0.009)$ ], with most nest entrances having a southern exposure and few facing east.

We also tested nest-entrance orientations for all species combined to examine the hypothesis that nest entrances were oriented toward woodland edge in riparian woodlands, regardless of compass heading. We found a significant difference between observed and expected distributions $\left(\chi^{2}=9.9, \mathrm{df}=1, P<0.01\right)$ indicating that overall nest orientations were consistent with orientation toward woodland edge. We next tested the hypothesis that species with significant foraging activity outside of riparian woodlands would be more likely to use cavities oriented toward woodland edge for efficient movement between nest cavity and foraging area. We grouped Northern Flicker, Tree Swallow, and European Starling together as species that forage largely outside of riparian woodlands (Dobkin et al., in prep.), and found that their nest cavities were oriented toward woodland edge (binomial test, $P=0.0002$ ). Sapsuckers, House Wrens, and Mountain Bluebirds were grouped as species that forage largely or entirely within riparian woodlands (Dobkin et al., in prep.), and their nest 

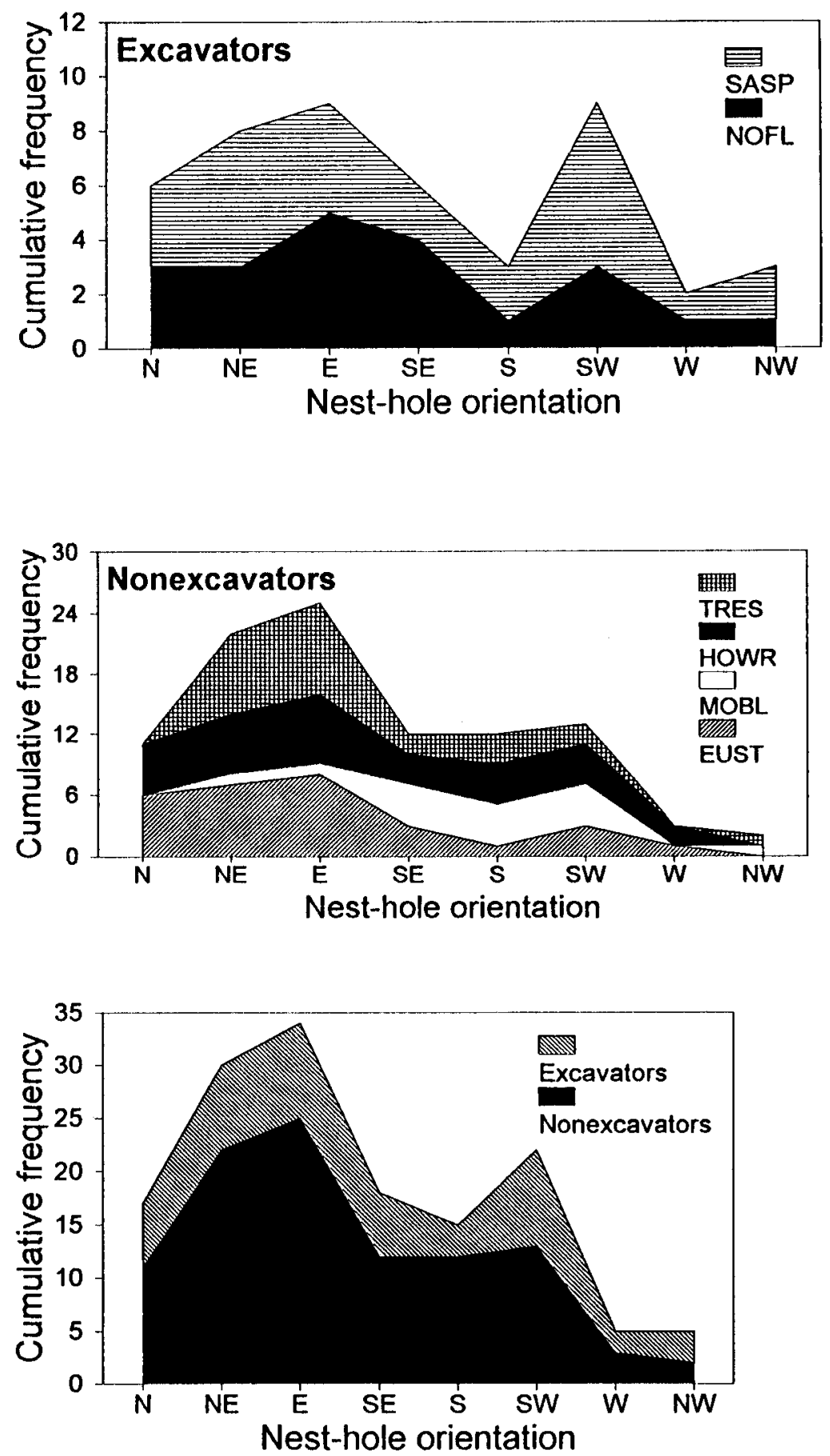

FIGURE 4. Cumulative frequency of nest-cavity entrance orientations for Red-naped Sapsucker (SASP), Northern Flicker (NOFL), Tree Swallow (TRES), House Wren (HOWR), Mountain Bluebird (MOBL), and European Starling (EUST) in aspen woodlands of Hart Mountain National Antelope Refuge, Oregon, 19921993. 


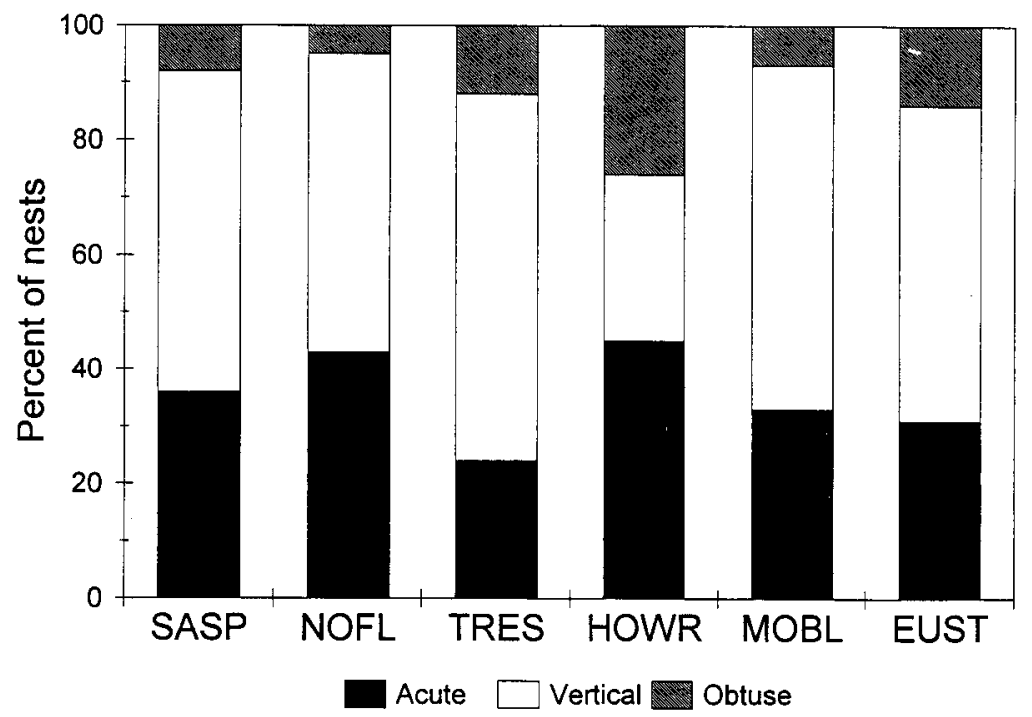

FIGURE 5. Distribution of nests on trees with acute, vertical, and obtuse bole angles (relative to nest-cavity entrances) for Red-naped Sapsucker (SASP), Northern Flicker (NOFL), Tree Swallow (TRES), House Wren (HOWR), Mountain Bluebird (MOBL), and European Starling (EUST) in aspen woodlands of Hart Mountain National Antelope Refuge, Oregon, 1992-1993.

cavities were found not to be oriented toward woodland edge (binomial test, $P=0.60$ ).

For most species, nest-tree bole angles relative to nest-cavity entrances were predominantly vertical (Fig. 5). House Wrens differed from all other nonexcavators $\left(\chi^{2}=8.3, P=0.02\right)$ by using mostly trees with acute angles, and proportionately more trees with obtuse angles (Fig. 5). Deviation of actual nest-tree bole angles from available angles could not be tested because cavity survey data were inadequate for computation of expected values.

Cluster analysis based on variables exhibiting significance in univariate analyses produced three species-pairs with decreasing degrees of nest site similarity (Fig. 6). Sapsuckers and Tree Swallows showed both the greatest similarity among species and the greatest separation from the other four species. Mountain Bluebirds and House Wrens exhibited a relatively high degree of similarity, but clustered much more closely with flickers and starlings than with sapsuckers and Tree Swallows.

\section{DISCUSSION}

\section{NESTING HABITAT}

Although they accounted for $<4 \%$ of all trees, aspen $>10 \mathrm{~m}$ in height and $>24 \mathrm{~cm}$ DBH clearly were favored as nest sites by cavity-nesting birds in montane aspen habitats. In spite of the much greater area occupied by snowpocket aspen woodlands, birds strongly preferred riparian aspen stands as nesting habitats, presumably due to the scarcity of large aspen in snowpockets. The widespread degradation of aspen and other riparian woodlands over the past 130 years in many parts of the Intermountain West (Kauffman 1990, U.S. Fish and Wildlife Service 1994) doubtlessly has reduced suitable nesting habitat and availability of nest sites for cavity-nesting species dependent upon large aspen trees.

Recruitment of young trees in these woodlands continues to be sporadic or entirely lacking as a result of intensive livestock grazing and fire suppression. This situation is analogous to cottonwood- (Populus spp.) dominated riparian areas described by Sedgwick and Knopf (1990) in which the absence of tree regeneration within aging woodlands leads inexorably to the loss of large live trees and snags without replacement, which in turn will result in significant declines of cavitynesting species. Structural restoration of these woodlands can be achieved through the use of fire to rejuvenate decadent aspen stands (Schier 1975, Jones and DeByle 1985, Bartos et al. 1991), although it is unclear how long it will take to 


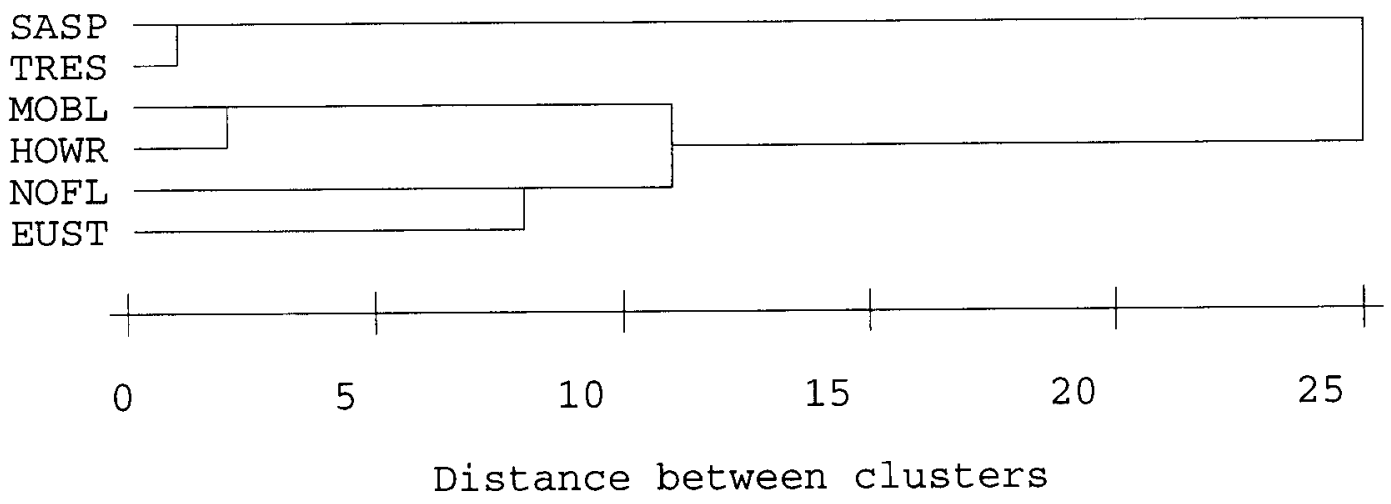

FIGURE 6. Cluster analysis dendrogram of nest-site relationships among cavity-nesting species based on nestsite characteristics in aspen woodlands of Hart Mountain National Antelope Refuge, Oregon, 1992-1993.

produce the amount and type of structure favored by cavity-nesting birds. The impact of prescribed fire on cavity-nesting birds remains unclear (Horton and Mannan 1988), however, and has not been examined in aspen woodlands.

Studies in other forest types have emphasized the importance of snag densities to cavity-nesting birds (Mannan et al. 1980, Raphael and White 1984, Zarnowitz and Manuwal 1985). In addition to the importance of snags for flickers, our findings underscore the importance of live trees with heartwood decay for cavity-nesting birds in aspen woodlands. Most cavity-bearing trees on Hart Mountain were live trees rather than snags, and nearly $75 \%$ of these trees supported visible shelf fungi. Other studies also note the importance of heartwood decay in live trees (especially aspen) for excavation of nest and roost cavities (Kilham 1971, Crockett and Hadow 1975, Conner et al. 1976, Harestad and Keisker 1989, Bull et al. 1992, Daily 1993).

\section{CAVITY ORIENTATION}

There is little agreement among studies of cavitynesting birds concerning the importance of cavity-entrance orientation. Several studies found significant directional orientation for cavity entrances (Lawrence 1967, Inouye 1976, Pinkowski 1976, Lumsden 1986, Rendell and Robertson 1994), which has been interpreted as microclimatically beneficial. Other studies failed to find significant differences from randomly distributed orientations, or viewed differences as incidental by-products of tree angle (Conner 1975). There is little agreement among studies even for species examined repeatedly in the same geographic re- gion, such as Gila Woodpeckers (Melanerpes uropygialis) nesting in saguaro cacti in Arizona (Inouye et al. 1981, Korol and Hutto 1984, Kerpez and Smith 1990b).

Nest-entrance orientations in our study were predominantly east and secondarily southwest, which may have conferred thermal advantages for reducing heat loss and enhancing development rates of eggs and nestlings in cool montane climates. Although the microclimatic consequences of differing nest orientations are reasonably well known for non-cavity nests (reviewed by Walsberg 1985), microclimates of enclosed tree cavities are largely a matter of conjecture. Within woodland or forest, canopy cover, time of day, and convective environment interact to produce microclimates (e.g., Rosenberg et al. 1983, Dobkin 1985, Stoutjesdijk and Barkman 1992) that greatly complicate any assumed relationship based simply on compass orientation or aspect. Thorough quantitative studies of the microclimatic consequences of cavity orientation in natural nest cavities have yet to be conducted (McComb and Noble 1981).

We found that the overall distribution of nestentrance orientations in these linear riparian woodlands also was consistent statistically with orientation toward woodland edges, which has not been considered in other studies. Species in our study that foraged outside of riparian woodland were more likely to use cavities oriented toward woodland edge compared with species that foraged within riparian woodlands. We agree with other investigators (Korol and Hutto 1984, Rendell and Robertson 1994) that it is unlikely for any single factor to account fully for the ori- 
entation of nest cavity entrances. We view microclimatic consequences of compass orientation, behavioral or microclimatic considerations favoring orientation toward woodland edge, and competition for preferred nest sites as likely interacting to produce the results seen in our study. We speculate that in contrast to other species, Mountain Bluebirds either preferentially selected southern exposures or were relegated to potentially less favorable nest microclimates by more aggressive species (European Starling, House Wren).

\section{INTERSPECIFIC RELATIONSHIPS}

Cavity-nesting birds can be limited in abundance by the availability of nest sites and resulting interspecific and intraspecific competition (Von Haartman 1957; Brush 1983; Brawn and Balda 1988; Kerpez and Smith 1990a, 1990b; Bock et al. 1992). Nest sites are not always limiting, however, and some studies document an excess of apparently suitable nest sites and the apparent absence of significant competitive interactions among cavity-nesting species (e.g., Waters et al. 1990).

At Hart Mountain, the paucity of large aspen favored for nest sites and the general absence of alternative woodlands in the vicinity of aspen groves provided conditions of potential nest-site limitation for cavity-nesting species. Although it is unlikely that our cavity survey located every available cavity on the study plots, we believe that our estimate of cavity availabilities was unbiased across plots and provided an accurate index to total cavity availability. Our estimates of avian relative abundances were based on birds assumed to be territorial, each of which presumably defended at least one cavity. Many cavitybearing trees harbored two or more cavities, and trees with cavities often occurred in close enough proximity to fall within individual cavity-nester territories. Hence, the close congruence between our relative abundance data for cavity-nesting species and the number of available cavity-bearing trees found in our cavity survey indicates the likelihood that few trees bearing cavities went unsequestered.

Although we have no direct evidence of interspecific competition for nest sites in our system, we infer from our data and from other studies that the potential for such competition in aspen woodlands of Hart Mountain is high, and may have been responsible in part for the observed distribution of nest sites occupied by Tree Swallows and Mountain Bluebirds.

Given the presence of open areas for foraging, Tree Swallows exhibit little specificity in nest site and habitat characteristics (Munro and Rounds 1985, Lumsden 1986, Parren 1991), and use nest cavities over a broad range of sizes. We found that although Tree Swallows used both flickerand sapsucker-excavated cavities, they relied heavily on the latter species with more than twothirds of their nests in sapsucker-excavated cavities. Our results are strikingly similar to other studies in which Tree Swallows disproportionately used nest cavities with the smallest diameters as a consequence of inferred competition with European Starlings (Peterson and Gauthier 1985, Rendell and Robertson 1989), which exclusively used flicker-excavated cavities in our study. Starlings compete aggressively for nest sites and can limit the abundance of native species (Short 1979; van Balen et al. 1982; Brush 1983; Ingold 1989, 1990; Kerpez and Smith 1990a). Gutzwiller and Anderson (1987) found that riparian areas in Colorado with high edge-to-interior ratios can be dominated overwhelmingly by starlings. In spite of their recent establishment in the Great Basin, starlings are now widespread throughout the region (Ryser 1985).

Tree Swallows also appeared to be limited to nest sites farther from woodland edges, possibly because starlings nested more frequently at grove edge sites. The only flicker-excavated cavities occupied by Tree Swallows were $>15 \mathrm{~m}$ from woodland edge, sites that presumably would be less attractive to starlings. In aspen parkland, starlings preferred nest sites on the edge of dense aspen stands (Peterson and Gauthier 1985), and other studies found starling nest locations to be inversely related to distance from grassy areas (e.g., Kerpez and Smith 1990a). Perhaps woodland edge nests decrease commute time and energy costs for cavity nesters that forage above or in open habitats, which should lead both European Starlings and Tree Swallows (Rendell and Robertson 1990) to prefer woodland edge sites.

Pinkowski (1976) found that Eastern Bluebirds ( $S$. sialis) nested in natural cavities with significantly smaller average entrance diameters in areas with starlings than in areas without starlings $(4.6 \mathrm{~cm}$ and $6.9 \mathrm{~cm}$, respectively). In our study, Mountain Bluebirds consistently nested in flicker-excavated cavities, which resulted in significant overlap in size of nest entrances used 
by bluebirds and starlings. The lack of use of sapsucker-excavated holes is surprising given that Mountain Bluebirds are smaller in length, wingspan, and mass than Red-naped Sapsuckers ( $\mathrm{Li}$ and Martin 1991, Dobkin, unpubl. data). Cavity depth, however, may be a more important selection criterion for Mountain Bluebirds than entrance diameter (Munro and Rounds 1985, Peterson and Gauthier 1985), which could result in relegation of bluebirds to flicker-excavated cavities that were less preferred by starlings. Competition between Tree Swallows and bluebirds for "starling-free" nest space also may have been a factor (Meek and Robertson 1994).

House Wrens were more abundant in aspen stands on Hart Mountain than all other species of cavity nesters combined (Dobkin et al., in prep.). Numerical dominance of cavity-nesting avifaunas in montane riparian woodlands (Finch 1990, Li and Martin 1991), broad plasticity in nest-site requirements (see also Munro and Rounds 1985), and well-known propensity to destroy both conspecific and allospecific eggs (BellesIsles and Picman 1986, Finch 1990), indicate the potential for House Wrens to exert a significant negative influence on populations of other cavity-nesting species in these habitats. Moreover, the House Wren's habit of filling nest cavities with sticks (Ehrlich et al. 1988) will deter other native species from using their cavities and could reduce overall cavity availability through time.

The cavity-nesting avifauna in Great Basin aspen woodlands (Dobkin and Wilcox 1986, Dobkin, in prep.) presents a rich opportunity for future experiments to test hypotheses regarding nest site limitation and competition through manipulations such as starling removal and nest box augmentation. From a conservation and land management perspective, starling removal is practical (Stewart 1973) and can increase the number of nesting native species, as demonstrated elsewhere in the Great Basin (Weitzel 1988).

\section{ACKNOWLEDGMENTS}

This research was supported by the United States Fish and Wildlife Service and by the High Desert Ecological Research Institute of Bend, Oregon. We thank J. Ahrens, B. Brown, R. Lange, C. Reeb, M. Remsberg, K. Smith, and especially A. Bunn for field assistance. T. Zimmerman and D. Alonso facilitated administrative and logistical support, and D. DeLong provided climbing gear. This paper benefited from reviews and comments by J. Buchanan, R. Mannan, C. Paige, W. Rendell, and M. Ryan.

\section{LITERATURE CITED}

Bartos, D. L., W. F. Mueggler, AND R. B. CAMPBell. 1991. Regeneration of aspen by suckering on burned sites in western Wyoming. U.S. For. Serv. Res. Paper INT-448.

Belles-Isles, J. D., AND J. Picman. 1986. House Wren nest-destroying behavior. Condor 88:190-193.

Birlings, W. D. 1990 . The mountain forests of North America and their environments, p. 47-86. In C. B. Osmond, L. F. Pitelka, and G. M. Hidy [eds.], Plant biology of the Basin and Range. SpringerVerlag, New York.

Bock, C. E., A. Cruz, Jr., M. C. Grant, C. S. Aid, AND T. R. Strong. 1992. Field experimental evidence for diffuse competition among southwestern riparian birds. Am. Nat. 140:815-828.

Brawn, J. D., AND R. P. Balda. 1988. Population biology of cavity nesters in northern Arizona: Do nest sites limit breeding densities? Condor 90:6171.

Brush, T. 1983. Cavity use by secondary cavitynesting birds and response to manipulations. Condor $85: 461-466$.

Bull, E. L., R. S. Holthausen, and M. G. Henjum. 1992. Roost trees used by Pileated Woodpeckers in northeastern Oregon. J. Wildl. Manage. 56:786793.

CONNER, R. N. 1975. Orientation of entrances to woodpecker nest cavities. Auk 94:371-374.

ConNer, R. N., O. K. MILler, JR., AND C. S. Adkisson. 1976. Woodpecker dependence on trees infected by fungal heart rots. Wilson Bull. 88:575-581.

Crockett, A. B., ANd H. H. Hadow. 1975. Nest site selection by Williamson and Red-naped Sapsuckers. Condor 77:365-368.

DAILY, G. C. 1993. Heartwood decay and vertical distribution of Red-naped Sapsucker nest cavities. Wilson Bull. 105:674-679.

DAY, R. W., AND G. P. QUINN. 1989. Comparisons of treatments after an analysis of variance in ecology. Ecol. Monogr. 59:433-463.

DoBKIN, D. S. 1985 . Heterogeneity of tropical floral microclimates and the response of hummingbird flower mites. Ecology 66:536-543.

DoBKIN, D. S. 1994. Conservation and management of Neotropical migrant landbirds in the Northern Rockies and Great Plains. Univ. Idaho Press, Moscow.

DoBKIn, D. S., AND B. A. WrLCOX. 1986. Analysis of natural forest fragments: riparian birds in the Toiyabe Mountains, Nevada, p. 293-299. In J. Verner, M. L. Morrison, and C. J. Ralph [eds.], Wildlife 2000: modeling habitat relationships of terrestrial vertebrates. Univ. of Wisconsin Press, Madison.

EHRLICH, P. R., D. S. DobkIn, AND D. WheYE. 1988. The birder's handbook: a field guide to the natural history of North American birds. Simon and Schuster, New York.

EmLen, J. T. 1971. Population densities of birds derived from transect counts. Auk 88:323-342.

EMLEN, J. T. 1977. Estimating breeding season bird densities from transect counts. Auk 94:455-468.

Finch, D. M. 1990. Effects of predation and com- 
petitor interference on nesting success of House Wrens and Tree Swallows. Condor 92:674-687.

FleischneR, T. L. 1994. Ecological costs of livestock grazing in western North America. Cons. Biol. 8:629-644.

GRUELL, G. E. 1985. Fire on the early western landscape: an annotated list of recorded wildfires in presettlement times. Northwest Sci. 59:97-107.

GuTzWILler, K. J., AND S. H. ANDERSON. 1987. Shortterm dynamics of cavity-nesting bird communities in disjunct floodplain habitats. Condor 89: $710-720$.

Harestad, A. S., AND D. G. Keisker. 1989. Nest tree use by primary cavity-nesting birds in south central British Columbia. Can. J. Zool. 67:1067-1073.

Horton, S. P., and R. W. Mannan. 1988. Effects of prescribed fire on snags and cavity-nesting birds in southeastern Arizona pine forests. Wildl. Soc. Bull. 16:37-44.

INGOLD, D. J. 1989. Nesting phenology and competition for nest sites among Red-headed and Redbellied Woodpeckers and the European Starling. Auk 106:209-217.

INGOLD, D. J. 1990. Simultaneous use of nest trees by breeding Red-headed and Red-bellied Woodpeckers and European Starlings. Condor 92:252253.

INOUYE, D. W. 1976. Nonrandom orientation of entrance holes to woodpecker nests in aspen trees. Condor 78:101-102.

INOUYE, R. S., N. J. Huntly, AND D. W. INOUYE. 1981. Nonrandom orientation of Gila Woodpecker nest entrances in saguaro cacti. Condor 83 : 88-89.

Johnson, N. K., AND C. B. Johnson. 1985. Speciation in sapsuckers (Sphyrapicus): II. Sympatry, hybridization, and mate preference in $S$. ruber daggetti and $S$. nuchalis. Auk 102:1-15.

JoHNSON, N. K., AND R. M. ZINK. 1983. Speciation in sapsuckers (Sphyrapicus): I. Genetic differentiation. Auk 100:871-884.

Johnson, R. R., C. D. Ziebell, D. R. Patton, P. F. FFolliot, AND R. H. HAMRE [TECHNICAL COORDINATORs]. 1985. Riparian ecosystems and their management: reconciling conflicting uses. U.S. For. Serv. Gen. Tech. Rep. RM-120.

JoNes, J. R., AND N. V. DEBylE. 1985. Fire, p. 7781. In N. V. DeByle and R. P. Winokur [eds.], Aspen: ecology and management in the western United States. U.S. For. Serv. Gen. Tech. Rep. RM-119.

KaUfFMAN, J. B. 1990 . The ecology of fire in rangelands: historical and current contexts, p. 2-5. In T. E. Bedell [ed.], Proc. 1990 Pacific Northwest range management short course: fire in Pacific Northwest ecosystems. Oregon State Univ., Corvallis.

KerPez, T. A., AND N. S. SMith. 1990a. Competition between European Starlings and native woodpeckers for nest cavities in saguaros. Auk 107:367375.

Kerpez, T. A., AND N. S. Smith. 1990b. Nest-site selection and nest-cavity characteristics of Gila Woodpeckers and Northern Flicker.

KILHAM, L. 1971. Reproductive behavior of Yellow- bellied Sapsuckers: I. Preference for nesting in Fomes-infected aspens and nest hole interrelations with flying squirrels, raccoons, and other animals. Wilson Bull. 83:159-171.

KNopf, F. L., R. R. Johnson, T. Rich, F. B. SAMson, AND R. C. Szaro. 1988. Conservation of riparian ecosystems in the United States. Wilson Bull. 100: 272-284.

Korol, J. J., AND R. L. Hutto. 1984. Factors affecting nest site location in Gila Woodpeckers. Condor 86:73-78.

LAWRENCE, L. D. 1967. A comparative life-history study of four species of woodpeckers. Ornithol. Monogr. No. 5, Am. Ornithol. Union. Lawrence, KS.

LI, P., AND T. E. MARTIN. 1991. Nest-site selection and nesting success of cavity-nesting birds in high elevation forest drainages. Auk 108:405-418.

LuMSDEN, H. G. 1986. Choice of nest boxes by Tree Swallows, Tachycineta bicolor, House Wrens, Troglodytes aedon, Eastern Bluebirds, Sialia sialis, and European Starlings, Sturnus vulgaris. Can. Field-Natur. 100:343-349.

Mannan, R. W., E. C. Meslow, and H. M. Wight. 1980. Use of snags by birds in Douglas-fir forests, western Oregon. J. Wildl. Manage. 44:787-797.

McComb, W. C., ANd R. E. Noble. 1981. Microclimates of nest boxes and natural cavities in bottomland hardwoods. J. Wildl. Manage. 45:284289.

MeEK, S. B., AND R. J. Robertson. 1994. Interspecific competition for nestboxes affects mate guarding in Eastern Bluebirds, Sialia sialis. Anim. Behav. 47:295-302.

MuNRO, H. L., AND R. C. Rounds. 1985. Selection of artificial nest sites by five sympatric passerines. J. Wildl. Manage. 49:264-276.

Norusis, M. J. 1993. SPSS for Windows: base system user's guide, release 6.0. SPSS Inc., Chicago.

PARREN, S. G. 1991. Evaluation of nest-box sites selected by Eastern Bluebirds, Tree Swallows, and House Wrens. Wildl. Soc. Bull. 19:270-277.

Peterson, B., and G. Gauthier. 1985. Nest site use by cavity-nesting birds of the Cariboo Parkland, British Columbia. Wilson Bull. 97:319-331.

PINkowskI, B. C. 1976 . Use of tree cavities by nesting Eastern Bluebirds. J. Wildl. Manage. 40:556-563.

Platts, W. S., C. Armour, G. D. Booth, M. Bryant, J. L. Bufford, P. Cuplin, S. Jensen, G. W. LienkaEMper, G. W. Minshall, S. B. Monsen, R. L. Nelson, J. R. Sedell, and J. S. Tuhy. 1987. Methods for evaluating riparian habitats with applications to management. U.S. For. Serv. Gen. Tech. Rep. INT-221.

RAPHAEL, M. G., AND M. White. 1984. Use of snags by cavity-nesting birds in the Sierra Nevada. Wildl. Monogr. 86:1-66.

ReNDELl, W. B., AND R. J. Robertson. 1989. Nestsite characteristics, reproductive success and cavity availability for Tree Swallows breeding in natural cavities. Condor 91:875-885.

RENDELL, W. B., AND R. J. ROBERTSON. 1990. Influence of forest edge on nest-site selection by Tree Swallows. Wilson Bull. 102:634-644.

RENDELl, W. B., AND R. J. RoBerTSON. 1994. Cavity- 
entrance orientation and nest-site use by secondary hole-nesting birds. J. Field Ornithol. 65:2735.

RosenberG, N. J., B. L. BLAD, AND S. B. VERMA. 1983. Microclimate: the biological environment. WileyInterscience, New York.

RYSER, F. A. 1985. Birds of the Great Basin: a natural history. Univ. of Nevada Press, Reno.

SaAb, V. A., C. E. Bock, T. D. Rich, and D. S. Dobkin. In press. Livestock grazing effects on migratory landbirds in western North America. In T. E. Martin and D. M. Finch [eds.], Ecology and management of Neotropical migratory birds: a synthesis and review of the critical issues. Oxford University Press, New York.

SchIER, G. A. 1975. Deterioration of aspen clones in the middle Rocky Mountains. U.S. For. Serv. Res. Paper INT-170.

SedGWICK, J. A., AND F. L. KNOPF. 1990. Habitat relationships and nest site characteristics of cavitynesting birds in cottonwood floodplains. J. Wildl. Manage. 54:112-124.

Short, L. L. 1979. Burdens of the Picid hole-excavating habit. Wilson Bull. 91:16-28.

Stewart, P. A. 1973. Replacement of cavity-hunting starlings and House Sparrows after removal. Wilson Bull. 85:291-294.

StoutJesdiuk, P., AND J. J. Barkman. 1992. Microclimate, vegetation and fauna. Opulus Press, Uppsala, Sweden.
Thomas, J. W., C. MAser, AND J. E. Rodiek. 1979. Wildlife habitats in managed rangelands - the Great Basin of southeastern Oregon. Riparian zones. U.S. For. Serv. Gen. Tech. Rep. PNW-80.

United States Fish and Wildlife Service. 1994. Hart Mountain National Antelope Refuge Comprehensive Management Plan. Volume 1. Portland, $O R$.

van Balen, J. H., C.J.H. Booy, J. A. Franeker, and E. R. OsIECK. 1982. Studies on hole nesting birds in natural nest sites. I. Availability and occupation of natural nest sites. Ardea 70:1-24.

Von HaArTMan, L. 1957. Adaptation in hole-nesting birds. Evolution 11:339-347.

WALSBerg, G. E. 1985. Physiological consequences of microhabitat selection, p. 389-413. In M. L. Cody [ed.], Habitat selection in birds. Academic Press, New York.

Waters, J. R., B. R. NoON, AND J. Verner. 1990. Lack of nest site limitation in a cavity-nesting bird community. J. Wildl. Manage. 54:239-245.

WeITZEL, N. H. 1988. Nest-site competition between the European Starling and native breeding birds in northwestern Nevada. Condor 90:515-517.

ZAR, J. H. 1984. Biostatistical Analysis. Second edition. Prentice-Hall, Englewood Cliffs, NJ.

Zarnowitz, J. E., ANd D. A. Manuwal. 1985. The effects of forest management on cavity-nesting birds in northwestern Washington. J. Wildl. Manage. 49:255-263. 